\title{
Neofabraea kienholzii, a novel causal agent of grapevine trunk diseases in Hungary
}

\author{
Szabina Lengyel • Dániel G. Knapp • Zoltán \\ Karácsony • József Geml • Balázs Tempfli • Gábor M. \\ Kovács • Kálmán Zoltán Váczy
}

Accepted: 11 June 2020 /Published online: 19 June 2020

(C) The Author(s) 2020

\begin{abstract}
Recently, more and more new fungal pathogens have been described as causal agents of grapevine trunk diseases (GTDs), which lead to increasingly significant economic losses in viticulture worldwide. The genus Neofabraea consists of species mainly known as important plant pathogens causing perennial canker and bull's eye rot, a common postharvest disease of apple (Malus domestica) and pear (Pyrus communis) fruits. Neofabraea kienholzii also causes lesions on pome fruits and canker on woody tissues, but its pathogenicity has not been demonstrated on grapevine yet. In 2015, two strains, identified as
\end{abstract}

S. Lengyel · D. G. Knapp · Z. Karácsony • B. Tempfli •

G. M. Kovács · K. Z. Váczy $(\bowtie)$

Food and Wine Research Institute, Eszterházy Károly University, Leányka u. 6, Eger H-3300, Hungary

e-mail: vaczy.kalman@uni-eszterhazy.hu

\section{S. Lengyel}

Institute of Biotechnology and Drug Research,

Erwin-Schrödinger-Str. 56, D-67663 Kaiserslautern, Germany

D. G. Knapp · G. M. Kovács

Department of Plant Anatomy, Institute of Biology, Eötvös

Loránd University, Pázmány Péter sétány 1/C, Budapest H-1117, Hungary

J. Geml

MTA-EKE Lendület Environmental Microbiome Research

Group, Eszterházy Károly University, Leányka u. 6, Eger H-3300, Hungary

\section{G. M. Kovács}

Plant Protection Institute, Centre for Agricultural Research, Hungarian Academy of Sciences (MTA-ATK), Budapest H-1525, Hungary
$N$. kienholzii based on ITS sequence data, were isolated from vines showing symptoms of GTDs in Hungary. For an unambiguous taxonomic placement of the isolates, four loci (ITS, LSU, TUB2 and RPB2) were amplified and sequenced. The phylogenetic analysis confirmed that the two isolates represent $N$. kienholzii. Pathogenicity tests performed on potted grapevines, shoots, and canes confirmed the virulence of these fungi. Their growth and sporulation on different media were also investigated. To the best of our knowledge, this is the first proof of $N$. kienholzii might cause symptoms on Vitis and might have a role in GTDs.

Keywords Grapevine trunk diseases · Helotiales · Vitis vinifera $\cdot$ Neofabraea kienholzii

Grapevine trunk diseases (GTDs) cause great economic losses in viticulture worldwide, due to the cost of replacement of dead grapevines that can excess 1.5 billion dollars per year (Hofstetter et al. 2012). The most important and severe diseases include eutypa dieback, esca complex and Petri disease, botryosphaeria dieback, phomopsis dieback, and black foot disease (de la Fuente Lloreda et al. 2016). However, examining the mycota of healthy and diseased plants of vineyards and rootstock, a high diversity of fungal taxa was found (Hofstetter et al. 2012). In Hungary, although vineyards have been monitored for GTDs since 2015, still little is known about the potential pathogens. Recently, the Tokaj Wine Region - a historically and economically important territory for winemaking in the north-eastern 
part of the country - was investigated to evaluate the occurrence of GTDs, focusing on the environmental factors affecting the incidence of Diplodia seriata, a pathogen involved in botryosphaeria dieback (Kovács et al. 2017). Two newly detected fungi have been also described: Seimatosporium vitis (Váczy 2017), an accompanying species of different main pathogens of GTDs, and Dothiorella omnivora (Váczy et al. 2018), a causal agent of botryosphaeria dieback.

The genus Neofabraea (Helotiales, Ascomycota) includes eight species (Johnston et al. 2004; Chen et al. 2016). These species represent fungal pathogens isolated from various plant species including apple and pear, on which $N$. kienholzii is known to cause perennial canker and bull's eye rot (Wenneker et al. 2017). While the economic significance of perennial canker is difficult to estimate, the post-harvest bull's eye rot was reported to cause 5-50\% yield losses depending on the examined vintage and crop variety (Gariepy et al. 2005). Although some strains of $N$. malicorticis have been isolated from healthy grapevines (Hofstetter et al. 2012) and a single isolate of $N$. kienholzii was isolated from Vitis trunk with GTD (Baranek et al. 2018), we are not aware of any reports of proof for Neofabraea causing GTD symptoms of Vitis cultivars.

In 2015, approximately 500 grapevines were monitored in 25 vineyards in five wine regions in Hungary and the number of GTD symptomatic plants was determined. In order to identify the causal agents, fungi were isolated from the trunks and characterized using general morphological and molecular tools based on sequencing of the internal transcribed spacer region (ITS) (Schoch et al. 2012). During these studies, two isolates showing $>97 \%$ internal transcribed spacer (ITS) rDNA sequence similarity with Neofabraea kienholzii were chosen for further investigations. In this study, in order to characterize the two isolates obtained from GTD-affected vines in Hungary and putatively identified as $N$. kienholzii, we aimed to: (i) provide an unambiguous taxonomic placement of the isolated strains by multilocus molecular phylogenetic analyses; (ii) study their morphology, growth and sporulation on different media; and (iii) carry out pathogenicity tests on grapevines.

Woody tissue samples were collected from grapevine plants showing typical GTD symptoms, e.g., foliar discoloration, stunted shoots, apoplexy (Mugnai et al. 1999; Sosnowski et al. 2007; Kuntzmann et al. 2010), from five wine regions (Eger, Neszmély, Pécs, Szekszárd, and Villány) in Hungary in 2015. Five thin discs were cut from asymptomatic and necrotic parts of the trunk. Bark tissue was removed, and the discs were surface-sterilized in $1 \%$ chloramine B solution for $5 \mathrm{~min}$, rinsed in sterile distilled water and dried between two layers of paper towels. Five small pieces were cut from the discs, placed on potato dextrose agar (PDA, Sigma-Aldrich, Germany) and incubated at $23-25{ }^{\circ} \mathrm{C}$. The growth of the fungi was monitored for four weeks and in order to obtain pure cultures, the individual colonies were transferred separately to new plates containing PDA. The isolates were identified based on their morphological and molecular properties.

Two strains showing colony morphology similar to that of Neofabraea species were isolated from trunks showing discoloration of leaves and necrotic lesions in the woody tissues. The strain T15377 was found in a 13year-old Chardonnay' vine from Neszmély Wine Region in North West Hungary (Fig. 1a). Besides this fungus, Diplodia seriata and Eutypa lata were also detected in the trunk. The strain T15671 was isolated from a 14-year-old Kékfrankos' from Eger Wine Region in North Hungary (Fig. 1b), together with Phaeomoniella chlamydospora and Phaeoacremonium minimum. In order to determine the species similar to Neofabraea, molecular characterization of the strains was performed. DNA was extracted from lyophilized non-sporulating cultures using DNeasy Plant Mini Kit (Qiagen, Germany) following manufacturer's instructions. The ITS and the partial 28S rDNA gene (LSU) were amplified and sequenced with ITS1 and ITS5 (White et al. 1990), and LR0R (Rehner and Samuels 1994) and LR5 (Vilgalys and Hester 1990) primer pairs, respectively. For further molecular phylogenetic characterization, partial B-tubulin (TUB2) and RNA polymerase II second largest subunit (RPB2) genes were amplified with the Bt-T2m-Up and Bt-LEV-Lo1 (de Jong et al. 2001), and RPB2-5F2 (Sung et al. 2007) and RPB2-7cr (Liu et al. 1999) primer pairs, respectively. The ITS, LSU, TUB2, and RPB2 sequences of the T15377 and T15671 strains were deposited in NCBI GenBank (Table 1). Both strains have been deposited at CBS-KNAW Culture Collection (Westerdijk Fungal Biodiversity Institute, Netherlands) (Table 1).

Alignments of our sequences with sequences of related species obtained from GenBank (Table 1) were assembled using E-INS-i method of the online MAFFT version 7 (Katoh and Standley 2013). The alignments were checked and edited in MEGA6 (Tamura et al. 2013). Multi-locus phylogenetic Bayesian analysis was 


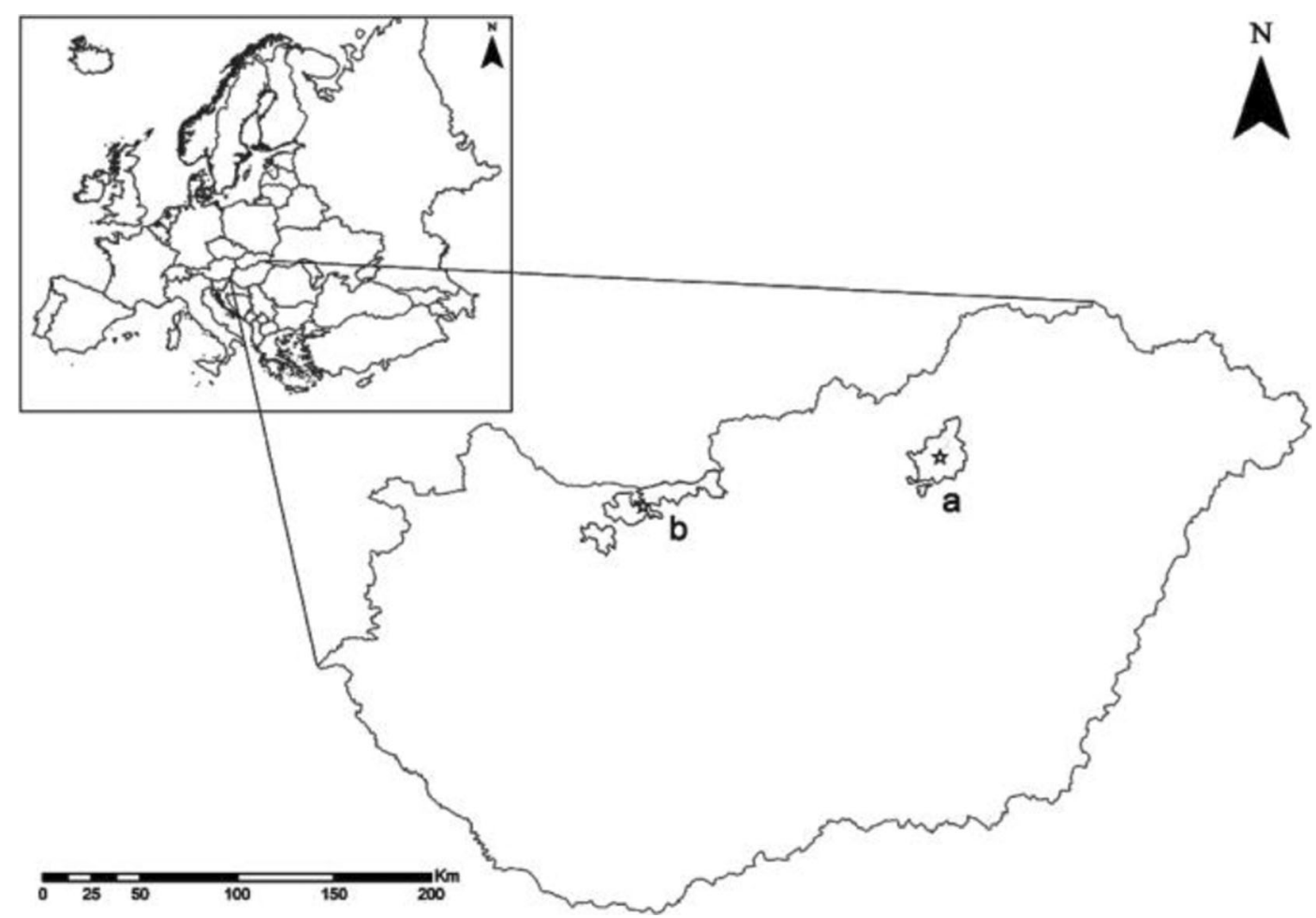

Fig. 1 Map indicating the origins of Neofabraea kienholzii isolates in Hungary. a Strain T15377 was collected in Eger Wine Region, b T15671 was collected in Neszmély Wine Region

performed with MrBayes 3.1.2 (Ronquist and Huelsenbeck 2003) using the GTR + G nucleotide substitution model. Four Markov chains were run for 10,000,000 generations sampled every 1000 generations with a burn-in value set at 4000 sampled trees. Topological convergence was checked by AWTY (Nylander et al. 2008). The maximum likelihood (ML) phylogenetic analysis was carried out with the raxmlGUI v. 1.3 (Silvestro and Michalak 2012) implementation of RAxML (Stamatakis 2014). The GTR + G nucleotide substitution model was used with ML estimation of base frequencies and a ML bootstrap analysis with 1000 replicates was used to test the support of the branches. The phylogenetic trees were visualized and edited using MEGA6 (Tamura et al. 2013).

Morphology and sporulation of the two isolates were examined on PDA, malt extract agar (MEA, SigmaAldrich, Germany), oatmeal agar (OA, Sigma-Aldrich, Germany), and water agar (WA, agar from SigmaAldrich, Germany) plates, with four technical replicates for each condition. Plates were incubated at $23-25{ }^{\circ} \mathrm{C}$ and colony diameter was measured evert day for 14 days. Conidia were obtained on OA and their size was determined with ImageJ software (Schneider et al.
2012) using a Bürker chamber as reference, measuring 100-100 conidia of each strain. Microscopic examinations were done by Alpha BIO-5f (Alpha) microscope equipped with an Artcam-500MI camera (Artray).

Pathogenicity tests were performed on young shoots, 1-year-old canes, and potted Blauburger' grapevines. Four shoots, canes, or potted plants were inoculated with agar plugs containing actively growing mycelium of the T15377 or T15671 strains and without mycelium, as control. Young shoots were surface sterilized with $70 \%$ alcohol, wounded with sterile scalpel and a $5 \mathrm{~mm}$ diameter PDA plug was placed on the wound and fixed with Parafilm M®. Shoots were kept in water at RT. During pruning, one cane of several vines was left to carry out pathogenicity tests. Canes were surface sterilized; a $5 \mathrm{~mm}$ diameter hole was drilled in each one and were inoculated as described above. Potted grapevines were inoculated following the same method as for the one-year-old canes. Symptoms were monitored after 14 days in case of young shoots, 5 months in case of canes, and two months in case of potted grapevines.

The T15377 and T15671 strains were re-isolated from the grapevine vascular tissues according to the subsequent protocol: about $2 \mathrm{~cm}$ above and below the inoculation 


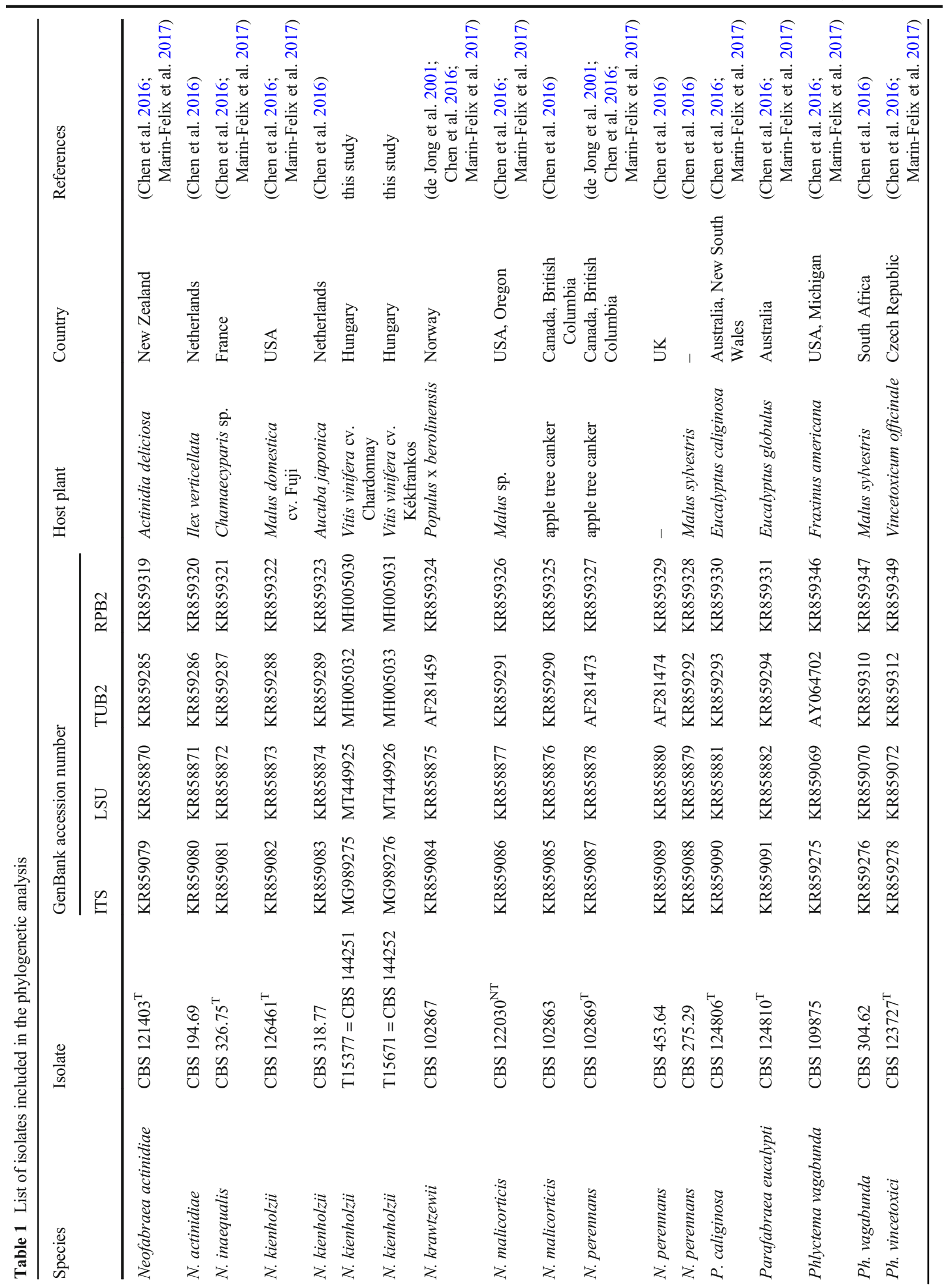


point discs were cut from the shoots and canes, were surface sterilized in sodium hypochlorite (4\% available chlorine $w / v$ ), rinsed in $70 \%$ alcohol and dried. Potted grapevines were cut vertically. Five pieces per replicate were placed on PDA and plates were incubated at 23$25{ }^{\circ} \mathrm{C}$ for one week, until the colonies appeared. The reisolated strains were verified by sequencing of their ITS region.

According to the multi-locus phylogenetic analysis, both isolates from Hungary (T15377 and T15671) belonged to the genus Neofabraea and formed a wellsupported clade with $N$. kienholzii isolates (Fig. 2). The difference in the ITS, LSU, TUB2 and RPB2 sequences of our isolates and other $N$. kienholzii strains CBS 318.77 and CBS 126461 (ex-type) was $0-0.2 \%$, 0\%, $0-0.3 \%$ and $0-0.1 \%$, respectively. The results of the molecular phylogenetic analyses unambiguously show that the two isolates are $N$. kienholzii.

After being kept at $23-25^{\circ} \mathrm{C}$ for 14 days, the colony diameter of the two strains showed significant difference on MEA (30 and $23.5 \mathrm{~mm}$ ), OA (42 and $39.5 \mathrm{~mm}$ ), and WA (34.5 and $18.5 \mathrm{~mm}$ ), but not on PDA (24 mm). Colonies on PDA were salmon or cream-colored covered with white radiating mycelium, white or greyish aerial mycelium in the center and wavy margin. On MEA, the strains showed similar morphologies as detected on PDA, but with smooth margin. Colonies on OA were yellowish, waxy, on WA cream-colored, on both media lacking the white cottony mycelium. Sporulation was detected at 14 days post inoculation (dpi) on OA. Microconidia were one-celled, oblong-ellipsoidal, and weakly to strongly curved of both strains (Fig. 3b). Slight variation was observed in the size of conidia in case of the examined strains $-5-8.5 \times 2.5-3.5 \mu \mathrm{m}$ of $\mathrm{T} 15377,4-7 \times 2-3.5 \mu \mathrm{m}$ of T15671 - and they were slightly bigger than the microconidia described for the same species before (Spotts et al. 2009; Wenneker et al. 2017). Macroconidia - rarely occurred - were onecelled, oblong-ellipsoidal, sometimes weakly curved (Fig. 3c), measuring $13 \times 3 \mu \mathrm{m}$ of each isolate. Conidiogenous cells of the colonies grown on OA forming macroconidia were also observed (Fig. 3a).

The virulence of the two isolates was confirmed by artificial inoculations under laboratory and field conditions. White mycelial mass appeared on the young shoots (Fig. 4a), suggesting the growth of the fungus on grapevine tissues. Cross section of one-year-old canes showed linear brown vascular coloration (Fig. 4b, d). Brown coloration was seen around the inoculation point in vertically cut 
Fig. 2 Maximum Likelihood (RAxML) tree of concatenated ITS, LSU, TUB2 and RPB2 sequences of representative species of Neofabraea and related genera. Bayesian posterior probabilities $(\geq 0.90)$ are shown above branches and before slashes, ML bootstrap support values $(\geq 70)$ are shown below branches and after slashes. Strains introduced in this study are shown in bold. Parafabraea eucalypti and $P$. caliginosa were used as outgroups. The scale bar indicates expected changes per site per branch

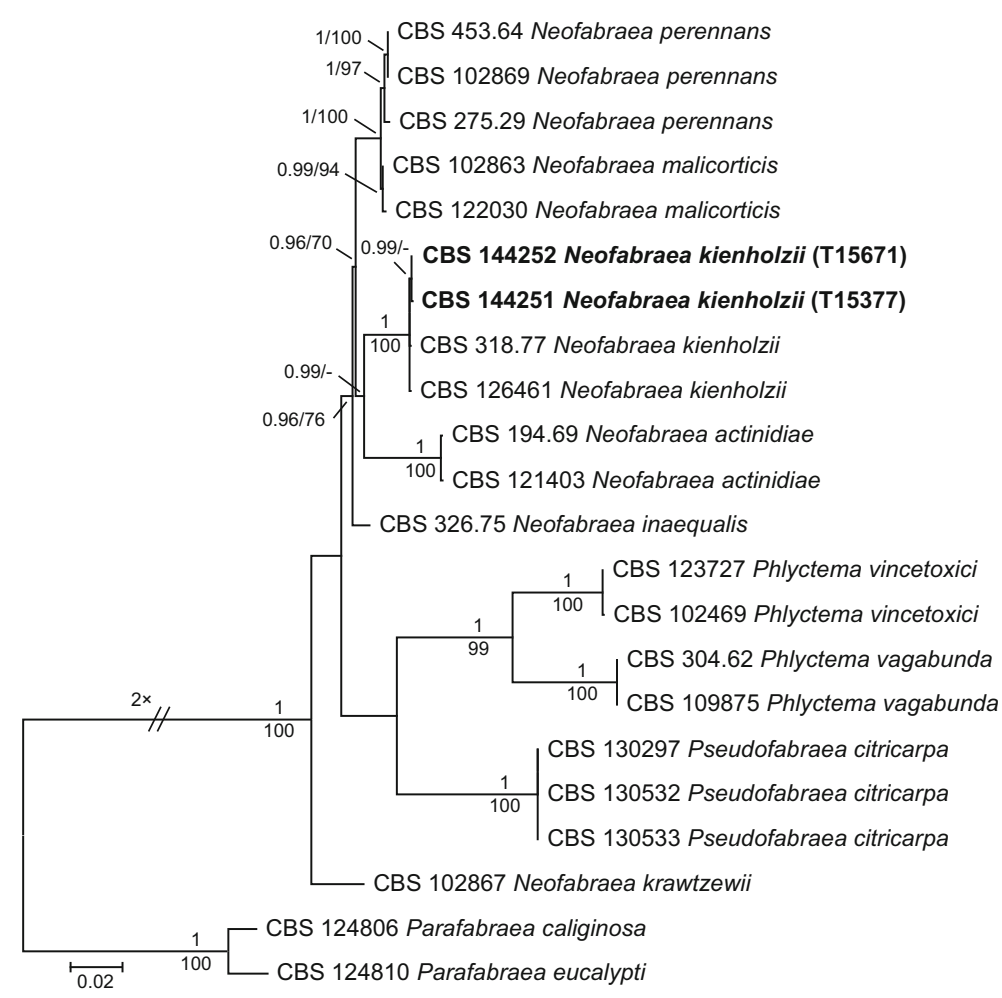

potted vines too (Fig. 4c). Neofabraea kienholzii was successfully re-isolated from the inoculated grapevines (Fig. 4e), and sequences of the ITS regions were identical to those of the previously described strains. Control plants remained symptomless.

According to morphological characteristics and the results of multi-locus molecular phylogenetic analyses, the two isolates examined causing typical symptoms of GTDs belong unambiguously to the species $N$. kienholzii. The helotialean genus Neofabraea represents a taxonomically challenging taxon that currently comprises eight species with diverse host preferences, including the type species of Phlyctema, $P$. vagabunda, which is the asexual morph of N. alba [current name: N. vagabunda] (Verkley 1999; Johnston et al. 2014; Chen et al. 2016). The first species - N. malicorticis - was described as a causal agent of apple
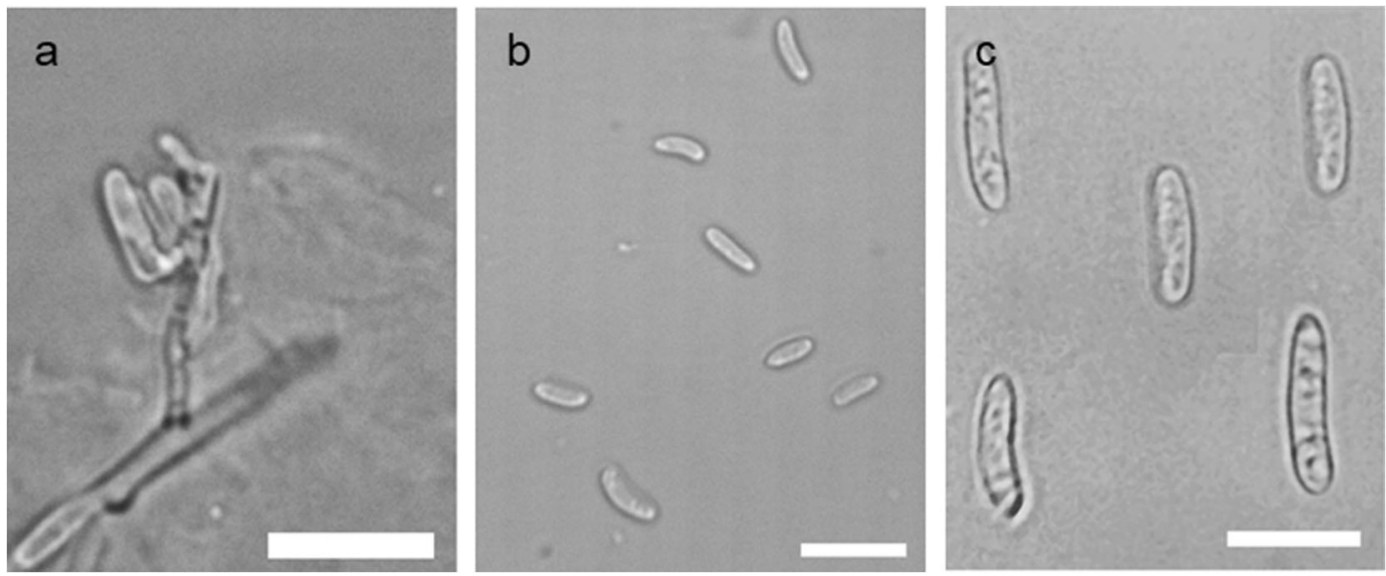

Fig. 3 Macro- and microconidia production of two Hungarian Neofabraea kienholzii isolates, induced on OA. a Conidiogenous cells of the strain T15377. b Microconidia of the strain T15377. c Composite photo of macroconidia of T15377 and T15671 strains. Scale bars: $10 \mu \mathrm{m}$ 


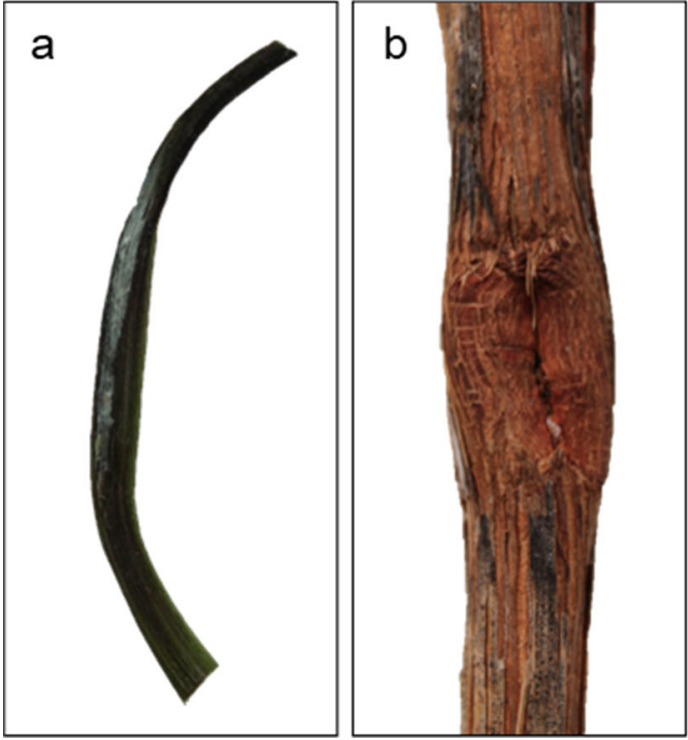

Fig. 4 Grapevine cv. Blauburger' inoculated with Hungarian Neofabraea kienholzii isolates. a Infection of young shoot at 14 dpi with white mycelium mass. $\mathbf{b}$, $\mathbf{d}$ Healed wound on a one-yearold cane after removal of the mycelial disc and cross section

anthracnose (Jackson 1913). In 1939, N. populi [current name: N. krawtzewii (Verkley 1999)] was isolated from poplar cankers and characterized (Thompson 1939), and was detected in Southern Finland also on poplar trees (Kasanen et al. 2002). Later, other fungal pathogens were reported causing perennial canker, bull's eye rot of apple and pear fruits, and described as Neofabraea or Pezicula alba, N. malicorticis, and N. perennans (Kienholz 1939; Guthrie 1959; Verkley 1999, and Abeln et al. 2000). The phylogenetic relationship among these taxa was first clarified by de Jong et al. (2001), suggesting the existence of $N$. malicorticis, $N$. perennans, $N$. alba, and an undetermined Neofabraea species. Regarding possible natural habitats, Neofabraea species have been detected in soil DNA sequences from tropical forests in Vietnam and Madagascar (Tedersoo et al. 2014) as well as from xerotherm oak forests in Hungary (Geml 2019), the latter being climatically ideal for grapevine cultivation. Currently, new species were isolated from different perennial plants: $N$. actinidiae from kiwifruit (Actinidia deliciosa) (Johnston et al. 2004), Cryptosporiopsis kienholzii (syn. Neofabraea kienholzii) from apple and pear (Spotts et al. 2009; Wenneker et al. 2017), N. brasiliensis from apple (Crous et al. 2015), N. inaequalis from Chamaecyparis sp. and $N$. actinidiae on winterberry (Ilex verticillata) (Chen et al. 2016). In subsequent morphological and phylogenetic analyses of the genus Neofabraea, Pezicula and some
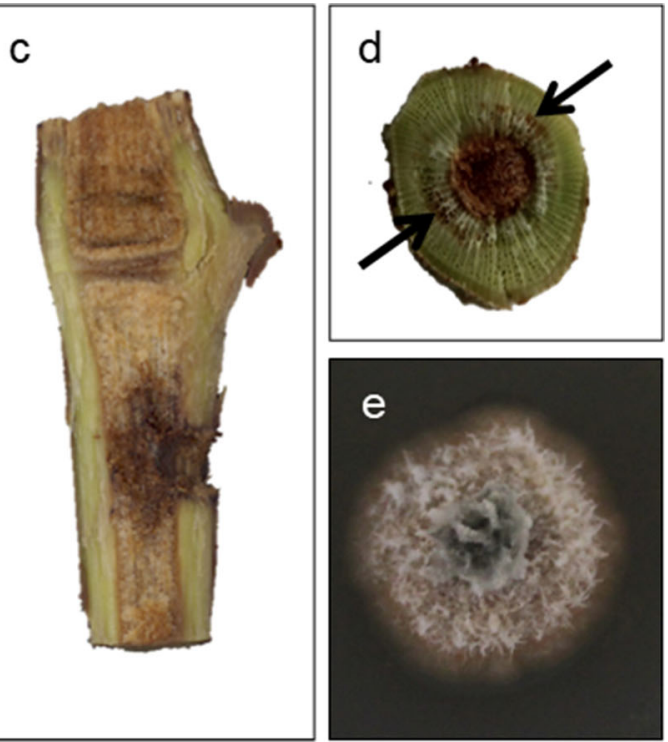

showing brown vascular coloration (arrows). c Infection of potted grapevine. Symptoms appeared as dark coloration of the vascular tissue around the inoculation point. e $N$. kienholzii isolated from grapevine wood growing on PDA

related genera, species were identified (Chen et al. 2016; Marin-Felix et al. 2017). During a survey seeking for the causing agents of esca disease, Hofstetter et al. (2012) obtained four isolates of $N$. malicorticis from healthy grapevines, although no connection to GTDs was established. So far, $N$. kienholzii has been known to cause bull's eye rot on apple and pear fruits accompanied with branch cankers (Spotts et al. 2009, Wenneker et al. 2017) and recently this species has been found on Japanese laurel (Aucuba japonica) as well (Chen et al. 2016). Although Baranek et al. (2018) reported a single $N$. kienholzii isolate from Vitis, no sequence data of that isolate is available, nor was any connection shown to GTDs.

Our study demonstrates, that $N$. kienholzii can infect grapevine causing brown vascular coloration in the canes, a characteristic symptom of GTDs. This observation supports the hypothesis that apple and pear trees that harbor fungi associated with dieback symptoms could serve as inoculum source of pathogens causing GTDs (Cloete et al. 2011). Furthermore, Gramaje et al. (2016) suggest that fungi associated with GTDs can infect other woody crops, such as pome and stone fruits, nut crops and olive trees as well. Because N. kienholzii already causes important damages on apple and pear, in time this pathogen may get more attention in viticulture, too. With this new report of a fungal genus causing disease on grapevine, our results contribute to the better understanding of the complex problem of GTDs. 
Acknowledgements This work was founded by the Széchenyi 2020 Programme the European Regional Development Fund and the Hungarian Government (GINOP-2.3.2-15-2016-00061). József Geml is supported by the Hungarian Academy of Sciences (MTA) Lendület Program (No. 96049). Gábor M. Kovács is supported by the ELTE Institutional Excellence Program supported by the National Research, Development and Innovation Office (NKFIH-1157-8/2019-DT). Kálmán Zoltán Váczy and Dániel G. Knapp are supported by the János Bolyai Research Scholarship of the Hungarian Academy of Sciences.

Funding Information Open access funding provided by Eszterhazy Karoly University.

Compliance with ethical standards This research and its presentation in this manuscript followed the rules of good scientific practice as described on the journal website.

Conflict of interest The authors declare no conflict of interest.

Human and animal studies This research did not involve human participants and animals.

Open Access This article is licensed under a Creative Commons Attribution 4.0 International License, which permits use, sharing, adaptation, distribution and reproduction in any medium or format, as long as you give appropriate credit to the original author(s) and the source, provide a link to the Creative Commons licence, and indicate if changes were made. The images or other third party material in this article are included in the article's Creative Commons licence, unless indicated otherwise in a credit line to the material. If material is not included in the article's Creative Commons licence and your intended use is not permitted by statutory regulation or exceeds the permitted use, you will need to obtain permission directly from the copyright holder. To view a copy of this licence, visit http://creativecommons.org/licenses/by/4.0/.

\section{References}

Abeln, E. C. A., de Pagter, M. A., \& Verkley, G. J. M. (2000). Phylogeny of Pezicula, Dermea and Neofabraea inferred from partial sequences of the nuclear ribosomal RNA gene cluster. Mycologia, 92, 685-693.

Baranek, M., Armengol, J., Holleinova, V., Pecenka, J., Calzarano, F., Penazova, E., Vachun, M., and Eichmeier, A. (2018). Incidence of symptoms and fungal pathogens associated with grapevine trunk diseases in Czech vineyards: first example from a north-eastern European grape-growing region. Phytopathologia Mediterranea, 57(3): 449-458.

Chen, C., Verkley, G. J. M., Sun, G., Groenewald, J. Z., \& Crous, P. W. (2016). Redefining common endophytes and plant pathogens in Neofabraea, Pezicula, and related genera. Fungal Biology, 120, 1291-1322.

Cloete, M., Fourie, P. H., Damm, U., Crous, P. W., \& Mostert, L. (2011). Fungi associated with die-back symptoms of apple and pear trees, a possible inoculum source of grapevine trunk disease pathogens. Phytopathologia Mediterranea, 50, S176-S190.

Crous, P. W., Wingfield, M. J., Le Roux, J. J., Richardson, D. M., Strasberg, D., Shivas, R. G., et al. (2015). Fungal planet description sheets: 371-399. Persoonia: Molecular Phylogeny and Evolution of Fungi, 35, 264-327.

De Jong, S. N., Levesque, C. A., Verkley, G. J. M., Abeln, E. C. A., Rahe, J. E., \& Braun, P. G. (2001). Phylogenetic relationships among Neofabraea species causing tree cankers and bull's-eye rot of apple based on DNA sequencing of ITS nuclear rDNA, mitochondrial rDNA, and the b-tubulin gene. Mycological Research, 105, 658-669.

De la Fuente Lloreda, M., Fontaine, F., Gramaje, D., Armengol, J., Smart, R., Nagy, Z. A., et al. (2016). Grapevine trunk diseases. A review. OIV publications, 1 st edition, Paris, ISBN = 979-10-91799-60-7.

Gariepy, T. D., Rahe, J. E., Lévesque, C. A., Spotts, R. A., Sugar, D. L., \& Henriquez, J. L. (2005). Neofabraea species associated with bull's-eye rot and cankers of apple and pear in the Pacific northwest. Canadian Journal of Plant Pathology, 27, 118-124.

Geml, J. (2019). Soil fungal communities reflect aspect-driven environmental structuring and vegetation types in a Pannonian forest landscape. Fungal Ecology, 39, 63-79.

Gramaje, D., Baumgartner, K., Halleen, F., Mostert, L., Sosnowski, M. R., Úrbez-Torres, J. R., \& Armengol, J. (2016). Fungal trunk diseases: A problem beyond grapevines? Plant Pathology, 65, 355-356.

Guthrie, E. J. (1959). The occurrence of Pezicula alba sp. nov. and P. malicorticis, the perfect states of Gloeosporium album and G. perennans, in England. Transactions of the British Mycological Society, 42, 502-506.

Hofstetter, V., Buyck, B., Croll, D., Viret, O., Couloux, A., \& Gindro, K. (2012). What if esca disease of grapevine were not a fungal disease? Fungal Diversity, 54, 51-67.

Jackson, H. S. (1913). Apple tree anthracnose. A preliminary report, Oregon Agricultural College Experiment Station. Biennial Crop Pest and Horticultural Report, 1911-1912, 178-197.

Johnston, P. R., Manning, M. A., Meier, X., Park, D., \& Fullerton, R. A. (2004). Cryptosporiopsi sactinidiae sp. nov. Mycotaxon, 89, 131-136.

Johnston, P. R., Seifert, K. A., Stone, J. K., Rossman, A. Y., \& Marvanová, L. (2014). Recommendations on generic names competing for use in Leotiomycetes (Ascomycota). IMA Fungus, 5, 91-120.

Kasanen, R., Hantula, J., \& Kurkela, T. (2002). Neofabraea populi in hybrid aspen stands in southern Finland. Scandinavian Journal of Forest Research, 17, 391-397.

Katoh, K., \& Standley, D. M. (2013). MAFFT multiple sequence alignment software version 7: Improvements in performance and usability. Molecular Biology and Evolution, 30, 772-780.

Kienholz, J. R. (1939). Comparative study of the apple anthracnose and perennial canker fungi. Journal of Agricultural Research, 59, 635-665.

Kovács, C., Balling, P., Bihari, Z., Nagy, A., \& Sándor, E. (2017). Incidence of grapevine trunk diseases is influenced by soil, topology and vineyard age, but not by Diplodia seriata infection rate in the Tokaj wine region, Hungary. Phytoparasitica, 45, 21-32. 
Kuntzmann, P., Villaume, S., Larignon, P., \& Bertsch, C. (2010). Esca, BDA and Eutypiosis: Foliar symptoms, trunk lesions and fungi observed in diseased vinestocks in two vineyards in Alsace. Vitis, 49, 71-76.

Liu, Y. J., Whelen, S., \& Hall, B. D. (1999). Phylogenetic relationships among ascomycetes: evidence from an RNA polymerase II subunit. Molecular Biology and Evolution, 16, 1799-1808.

Marin-Felix, Y., Groenewald, J. Z., Cai, L., Chen, Q., Marincowitz, S., Barnes, I., Bensch, K., Braun, U., Camporesi, E., Damm, U., de Beer, Z. W., Dissanayake, A., Edwards, J., Giraldo, A., Hernández-Restrepo, M., Hyde, K. D., Jayawardena, R. S., Lombard, L., Luangsaard, J., McTaggart, A. R., Rossman, A. Y., Sandoval-Denis, M., Shen, M., Shivas, R. G., Tan, Y. P., van der Linde, E. J., Wingfield, M. J., Wood, A. R., Zhang, J. Q., Zhang, Y., \& Crous, P. W. (2017). Genera of phytopathogenic fungi: GOPHY 1. Studies in Mycology, 86, 99-216.

Mugnai, L., Graniti, A., \& Surico, G. (1999). Esca (black measles) and brown wood-streaking: two old and elusive diseases of grapevines. Plant Disease, 83, 404-418.

Nylander, J. A., Wilgenbusch, J. C., Warren, D. L., Swofford, D., \& L. (2008). AWTY (are we there yet?): a system for graphical exploration of MCMC convergence in Bayesian phylogenetic inference. Bioinformatics, 24, 581-583.

Rehner, S. A., \& Samuels, G. J. (1994). Taxonomy and phylogeny of Gliocladium analysed from nuclear large subunit ribosomal DNA sequences. Mycological Research, 98, 625-634.

Ronquist, F., \& Huelsenbeck, J. P. (2003). MrBayes 3: Bayesian phylogenetic inference under mixed models. Bioinformatics, 19, 1572-1574.

Schneider, C. A., Rasband, W. S., \& Eliceiri, K. W. (2012). NIH image to ImageJ: 25 years of image analysis. Nature Methods, 9, 671-675.

Schoch, C. L., Seifert, K. A., Huhndorf, S., Robert, V., Spouge, J. L., Levesque, C. A., Chen, W., Fungal Barcoding Consortium, Fungal Barcoding Consortium Author List, Bolchacova, E., Voigt, K., Crous, P. W., Miller, A. N., Wingfield, M. J., Aime, M. C., An, K. D., Bai, F. Y., Barreto, R. W., Begerow, D., Bergeron, M. J., Blackwell, M., Boekhout, T., Bogale, M., Boonyuen, N., Burgaz, A. R., Buyck, B., Cai, L., Cai, Q., Cardinali, G., Chaverri, P., Coppins, B. J., Crespo, A., Cubas, P., Cummings, C., Damm, U., de Beer, Z. W., de Hoog, G. S., del-Prado, R., Dentinger, B., Dieguez-Uribeondo, J., Divakar, P. K., Douglas, B., Duenas, M., Duong, T. A., Eberhardt, U., Edwards, J. E., Elshahed, M. S., Fliegerova, K., Furtado, M., Garcia, M. A., Ge, Z. W., Griffith, G. W., Griffiths, K., Groenewald, J. Z., Groenewald, M., Grube, M., Gryzenhout, M., Guo, L. D., Hagen, F., Hambleton, S., Hamelin, R. C., Hansen, K., Harrold, P., Heller, G., Herrera, C., Hirayama, K., Hirooka, Y., Ho, H. M., Hoffmann, K., Hofstetter, V., Hognabba, F., Hollingsworth, P. M., Hong, S. B., Hosaka, K., Houbraken, J., Hughes, K., Huhtinen, S., Hyde, K. D., James, T., Johnson, E. M., Johnson, J. E., Johnston, P. R., Jones, E. B. G., Kelly, L. J., Kirk, P. M., Knapp, D. G., Koljalg, U., Kovacs, G. M., Kurtzman, C. P., Landvik, S., Leavitt, S. D., Liggenstoffer, A. S., Liimatainen, K., Lombard, L., Luangsa-ard, J. J., Lumbsch, H. T., Maganti, H., Maharachchikumbura, S. S. N., Martin, M. P., May, T.
W., McTaggart, A. R., Methven, A. S., Meyer, W., Moncalvo, J. M., Mongkolsamrit, S., Nagy, L. G., Nilsson, R. H., Niskanen, T., Nyilasi, I., Okada, G., Okane, I., Olariaga, I., Otte, J., Papp, T., Park, D., Petkovits, T., PinoBodas, R., Quaedvlieg, W., Raja, H. A., Redecker, D., Rintoul, T. L., Ruibal, C., Sarmiento-Ramirez, J. M., Schmitt, I., Schussler, A., Shearer, C., Sotome, K., Stefani, F. O. P., Stenroos, S., Stielow, B., Stockinger, H., Suetrong, S., Suh, S. O., Sung, G. H., Suzuki, M., Tanaka, K., Tedersoo, L., Telleria, M. T., Tretter, E., Untereiner, W. A., Urbina, H., Vagvolgyi, C., Vialle, A., Vu, T. D., Walther, G., Wang, Q. M., Wang, Y., Weir, B. S., Weiss, M., White, M. M., Xu, J., Yahr, R., Yang, Z. L., Yurkov, A., Zamora, J. C., Zhang, N., Zhuang, W. Y., \& Schindel, D. (2012). Nuclear ribosomal internal transcribed spacer (ITS) region as a universal DNA barcode marker for Fungi. Proceedings of the National Academy of Sciences., 109, 6241-6246.

Silvestro, D., \& Michalak, I. (2012). raxmlGUI: a graphical frontend for RAxML. Organisms Diversity and Evolution, 12, 335-337.

Sosnowski, M. R., Shtienberg, D., Creaser, M. L., Wicks, T. J., Lardner, R., \& Scott, E. S. (2007). The influence of climate on foliar symptoms of Eutypa dieback in grapevines. Phytopathology, 97, 1284-1289.

Spotts, R. A., Seifert, K. A., Wallis, K. M., Sugar, D., Xiao, C. L., Serdani, M., \& Henriquez, J. L. (2009). Description of Cryptosporiopsis kienholzii and species profiles of Neofabraea in major pome fruit growing districts in the Pacific Northwest USA. Mycological Research, 113, 13011311.

Stamatakis, A. (2014). RAxML version 8: a tool for phylogenetic analysis and post-analysis of large phylogenies. Bioinformatics, 30, 1312-1313.

Sung, G.-H., Sung, J.-M., Hywel-Jones, N. L., \& Spatafora, J. W. (2007). A multigene phylogeny of Clavicipitaceae (Ascomycota, Fungi): identification of localized incongruence using a combinational bootstrap approach. Molecular Phylogenetics and Evolution, 44, 1204-1223.

Tamura, K., Stecher, G., Peterson, D., Filipski, A., \& Kumar, S. (2013). MEGA6: molecular evolutionary genetics analysis version 6.0. Molecular Biology and Evolution, 30, 27252729.

Tedersoo, L., Bahram, M., Põlme, S., Köljalg, U., Yorou, N. S., Wijesundera, R., et al. (2014). Global diversity and geography of soil fungi. Science, 346, 1256688.

Thompson, G. (1939). A canker disease of poplars caused a new species of Neofabraea. Mycologia, 31, 455-465.

Váczy, K. Z. (2017). First report of Seimatosporium vitis associated with grapevine trunk disease symptoms in Hungary. Plant Disease, 101, 253.

Váczy, K. Z., Németh, M. Z., Csikós, A., Kovács, G. M., \& Kiss, L. (2018). Dothiorella omnivora isolated from grapevine with trunk disease symptoms in Hungary. European Journal of Plant Pathology, 150, 817-824.

Verkley, G. J. M. (1999). A monograph of the genus Pezicula and its anamorphs. Studies in Mycology, 44, 1-180.

Vilgalys, R., \& Hester, M. (1990). Rapid genetic identification and mapping of enzymatically amplified ribosomal DNA from 
several Cryptococcus species. Journal of Bacteriology, 172, 4238-4246.

Wenneker, M., Pham, K. T. K., Boekhoudt, L. C., de Boer, F. A., van Leeuwen, P. J., Hollinger, T. C., \& Thomma, B. P. H. J. (2017). First report of Neofabraea kienholzii causing bull's eye rot on pear (Pyruscommunis) in the Netherlands. Plant Disease, 101, 634.
White, T. J., Bruns, T., Lee, S., \& Taylor, J. (1990). Amplification and direct sequencing of fungal ribosomal RNA genes for phylogenetics. In M. A. Innis, D. H. Gelfand, J. J. Sninsky, \& T. J. White (Eds.), PCR protocols: A guide to methods and applications (pp. 315-322). San Diego: Academic Press. 